Boletín de la Sociedad Geológica Mexicana

VolUMEN 64, NÚM. 1, 2012, P. 71-77

\title{
Pedogenetic Features of Habitation Deposits in Ancient Towns of European Russia and their Alteration under Different Natural Conditions
}

\author{
Alexander L. Alexandrovskiy ${ }^{1, *}$, Andrey V. Dolgikh ${ }^{1}$ and Elena I. Alexandrovskaya ${ }^{1}$ \\ ${ }^{1}$ Institute of Geography, Russian Academy of Sciences, Staromonetnyi per. 29, Moscow, 119017 Russia \\ *alexandrovskiy@mail.ru
}

\begin{abstract}
Over the centuries, layers of habitation deposits (or archaeological cultural layers) of up to 5-10 $\mathrm{m}$ in thickness have formed in towns and cities of European Russia. These specific deposits may be referred to as urbo-sediments. They consist mainly of the remains of buildings constructed out of wood, stones, bricks, or other materials and may also include traces of manure and diverse municipal wastes. Their composition and morphology depend on the natural conditions of the territory. In the humid northern forest regions of European Russia, the accumulation of wood remains, manure, and other organic substances is active. Thus, organic urbo-sediments are formed and the decomposition of organic matter in the deposits is hampered due to the high moisture content. In the ancient and medieval towns in the semiarid zone of southern Russia, such deposits consist of remains of mudbrick or adobe made of loess. Over the course of time, these deposits have been transformed as a result of the impact of pedogenetic processes developing under humid conditions in the North and under arid conditions in the South. In ancient towns in the forest zone with humid climate and poor drainage conditions, thick urbo-organic layers, consisting of a peatlike mass saturated with woody remains, have formed, whereas in the steppe zone, urbo-mineral sediments have developed.
\end{abstract}

Keywords: geoarchaeology, cultural layer, urban soil, pedogenic processes, ancient towns, European Russia.

\section{Resumen}

A lo largo de los siglos, capas de depósitos de habitación (o capas culturales arqueológicas) de hasta 5 a $10 \mathrm{~m}$ de espesor se han formado en pueblos y ciudades de la Rusia Europea. En particular, estos depósitos pueden ser referidos como urbo-sedimentos. Ellos están constituidos principalmente por restos de edificaciones construidas de madera, piedras, ladrillos u otros materiales, los cuales también pueden contener abono y diversos deshechos municipales. Su composición y morfología dependen de las condiciones naturales del territorio. En los bosques de las regiones septentrionales húmedas de la Rusia Europea, la acumulación de restos de madera, abono y otras sustancias orgánicas es activa. Por lo tanto, se forman urbo-sedimentos orgánicos y la descomposición de la materia orgánica en los depósitos se obstaculiza debido a su alta humedad. En los antiguos y medievales pueblos localizados en la zona semi-árida del sur de Rusia, tales depósitos consisten de restos de ladrillos de adobe o adobe hecho de loess. Con el transcurso del tiempo, estos depósitos han sido transformados como consecuencia del impacto de los procesos pedogenéticos que se desarrollan bajo condiciones húmedas en el Norte y bajo condiciones áridas en el Sur. En los pueblos antiguos de la zona forestal con un clima húmedo y pobres condiciones de drenaje, se han formado gruesas capas urbo-orgánicas, que consisten de turbas saturadas con restos de madera; mientras, en la zona de la estepa, se han desarrollado sedimentos urbo-minerales.

Palabras clave: geoarqueología, capa cultural, suelo urbano, procesos pedogenéticos, pueblos antiguos, Rusia Europea. 


\section{Introduction}

The cultural deposits of ancient towns in European Russia, represented by thick layers partially transformed by pedogenesis and containing the profiles of weakly developed buried soils, as well as the underlying initial natural soils, have been studied. These deposits can be referred to as urbosediments, or as urban habitation deposits. In the central parts of ancient towns, such deposits may reach a maximum thickness of up to $10 \mathrm{~m}$, or even $20 \mathrm{~m}$ in depressions.

Extensive archaeological excavations in the center of ancient towns provide the opportunity to analyze the entire thickness of urban habitation deposits and to reconstruct the history of human activity in the past. At present, urban soils are mainly studied to assess the modern state of urban systems (Agarkova et al., 1991; Blume, 1989; Burghard, 1994; Lehmann and Stahr, 2007; Norra and Stüben, 2003; Stroganova and Agarkova, 1992; Stroganova et al., 1998). Generally, only the upper $2 \mathrm{~m}$ thick layer of urban soils and underlying sediments are considered. However, to understand the genesis and ecology of urban soils and urban landscapes, we should study the entire history of their development (Alexandrovskaya et al., 2001; Alexandrovskiy and Alexandrovskaya, 2005, 2009).

Although the urban habitation deposits in question have a great thickness, they are subject to the influence of pedolithogenic transformation processes and differ depending on particular climatic conditions and biota (Dolgikh, 2010). In turn, these differences affect the ecological properties and functions of urban habitation deposits, including the concentrations of microelements and various components affecting building foundations and municipal infrastructure (Alexandrovskaya and Alexandrovskiy, 2000; Sedov et al., 1999; Stroganova et al., 1998; Evdokimova, 1986).

\section{Objects and Methods}

Urban habitation deposits formed in different natural zones were studied (Figure 1), including ancient cities in the forest zone of European Russia functioning since the $8^{\text {th }}$ century AD (Staraya Ladoga), the $10^{\text {th }}$ century AD (Velikii Novgorod, Rostov Velikii), the $11^{\text {th }}$ century AD (Staraya Russa, Yaroslavl), and the $12^{\text {th }}$ century AD (Moscow). In the steppe zone, cities in the coastal area of the Black Sea and the Sea of Azov were investigated: Tanais ( $3^{\text {rd }}$ century $\mathrm{BC}-5^{\text {th }}$ century AD), Phanagoria $\left(6^{\text {th }}\right.$ century $\mathrm{BC}-9^{\text {th }}$ century $\mathrm{AD})$, and Hermonassa-Taman ( $6^{\text {th }}$ century BC-present time). In the humid forest zone, the mean annual temperatures vary within the range of $3-5^{\circ} \mathrm{C}$ and the mean annual precipitation is approximately $500-650 \mathrm{~mm}$; the precipitation-to-potential evaporation ratio (the humidity factor) is about 1.1-1.4. In the semiarid dry steppe zone, the mean annual temperatures are higher $\left(9-11^{\circ} \mathrm{C}\right)$; the mean annual precipitation is about $350-450 \mathrm{~mm}$, and the humidity factor is $0.4-0.6$.

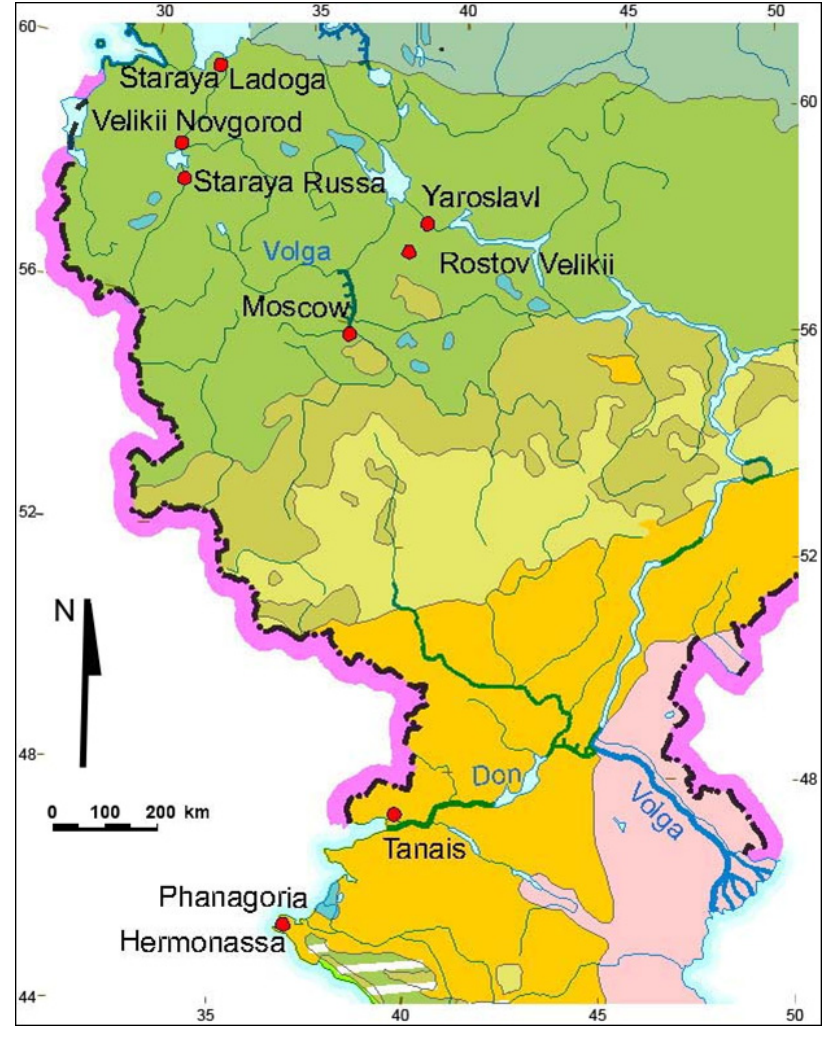

Figure 1. Location of studied sites.

The cities studied in the forest zone are located on low (Velikii Novgorod, Yaroslavl, Rostov Velikii) and high (Moscow) terraces of rivers and lakes. Terrace deposits are mainly represented by late Pleistocene loams and clays; in Moscow in particular, they consist of late Pleistocene loams underlain by sands. The cities studied in the steppe zone are situated on the terraces of the Taman Peninsula (Phanagoria and Hermonassa) composed of Pliocene sands and loams, and on the Don River terrace (Taman) composed of late Pleistocene loams underlain by limestone.

The following properties of urban sediments were studied: $\mathrm{pH}$ of water in suspension (potentiometric method); organic carbon content by Tyurin's method of bichromate oxidation (Aleksandrova and Naidenova, 1976); the content of carbonates by loss on ignition known as Kozlovkii's method (Vorobyova, 1998); total phosphorus content, particle-size distribution (pyrophosphate pretreatment), and bulk elemental analysis by X-ray fluorescence analysis. The age of the deposits was determined by the presence of cultural materials of previously established age.

\subsection{Forest zone}

The formation of habitation deposits in the ancient cities took place in two stages of predominant wooden construction (prior to the $18^{\text {th }}$ century), followed by stone construction (Alexandrovskaya and Alexandrovskiy, 2000; Dolgikh and Alexandrovskiy, 2010). The first stage 
is characterized by the accumulation of an urbo-organic layer composed of wooden chips, a peatlike mass from manure and the remains of buildings made of wood (Figure 2). The stage of stone construction is characterized by the accumulation of an urban-mineral layer composed of the debris of bricks, stones, lime, sand, and clay with some inclusions of organic matter. Fragments of pottery and animal bones are present in both layers.

The morphology of urban sediments and the underlying buried soil in Velikii Novgorod (the Ilmensky excavation) is shown in Figure 3. The soils buried under the habitation deposits are heavily loamy to clayey gleyed soddy-podzolic soils (Stagnic Albeluvisols); often, they have a plow horizon (Ap) with a thickness of up to $12 \mathrm{~cm}$. The characteristic features of former plowing were identified under the cultural layers at the base level of the plow horizon in the excavation

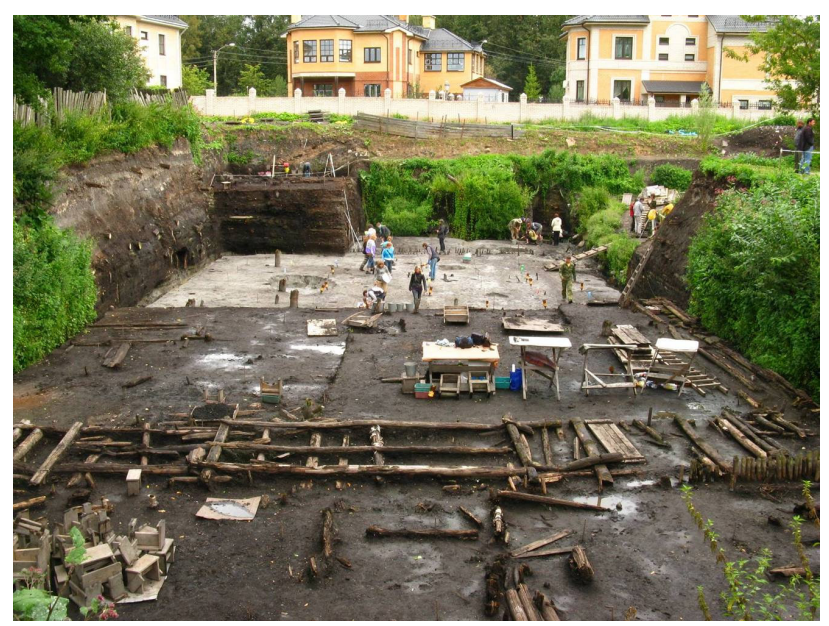

Figure.2. Velikii Novgorod, the Troitsky-XIII, XIV excavation. The remains of the medieval woody pavement are seen in the foreground. at Troitsky-X (Alexandrovskaya et al., 2001). The thickness of the eluvial horizon is 15 to $30 \mathrm{~cm}$. Following the burial of the soil under the thick layer of habitation deposits and the rise in the groundwater level, gleyzation was enhanced. The organic carbon content decreased to $2 \%$. The acid reaction typical of the background soddy-podzolic soils (Stagnic Albeluvisols, $\mathrm{pH} 4.8-5.3)$ was replaced by a neutral to alkaline reaction $(\mathrm{pH} 6.2$ in the Ap horizon and $\mathrm{pH} 7.5-8.3$ in the Eg and Btg horizons) resulting from carbonates in the habitation deposits. The processes of carbonate leaching and illuviation of fine earth from the habitation deposits into the underlying soil are clearly seen in fissures; the leaching of phosphorus compounds resulted in the formation of kerchenite represented by bluish films in the Eg and Btg horizons (Figure 4).

The urbo-organic sediments overlying the buried natural soil (OL, Figure 5) are saturated with water during a large part of the year. The raw organic material (peatlike mass) consists of the remains of herbs and straw (manure) and well-preserved wooden chips (Dolgikh and Alexandrovskiy, 2010). They also contain inclusions of the medium loamy mineral matter with limestone debris, various artifacts, wooden pavements, and logs. In the central part of the city (Troitsky-XIII, XIV excavations, Figure 2), the thickness of this layer reaches 3-4 $\mathrm{m}$. The portion of organic material in the organic layer varies from 50 to $90 \%$ (by volume). The organic horizons in the urban sediments prior to the $18^{\text {th }}$ century have the most acid reaction in the entire profile ( $\mathrm{pH}<5.8)$. The surface of aggregates is covered by films of kerchenite. These horizons are rich in phosphorus (1-3\%). Ash interlayers effervesce with $\mathrm{HCl}$ and are an important source of carbonates in the habitation deposits (Alexandrovskiy, 2007).

The overlying dark gray urbo-organic-mineral layer

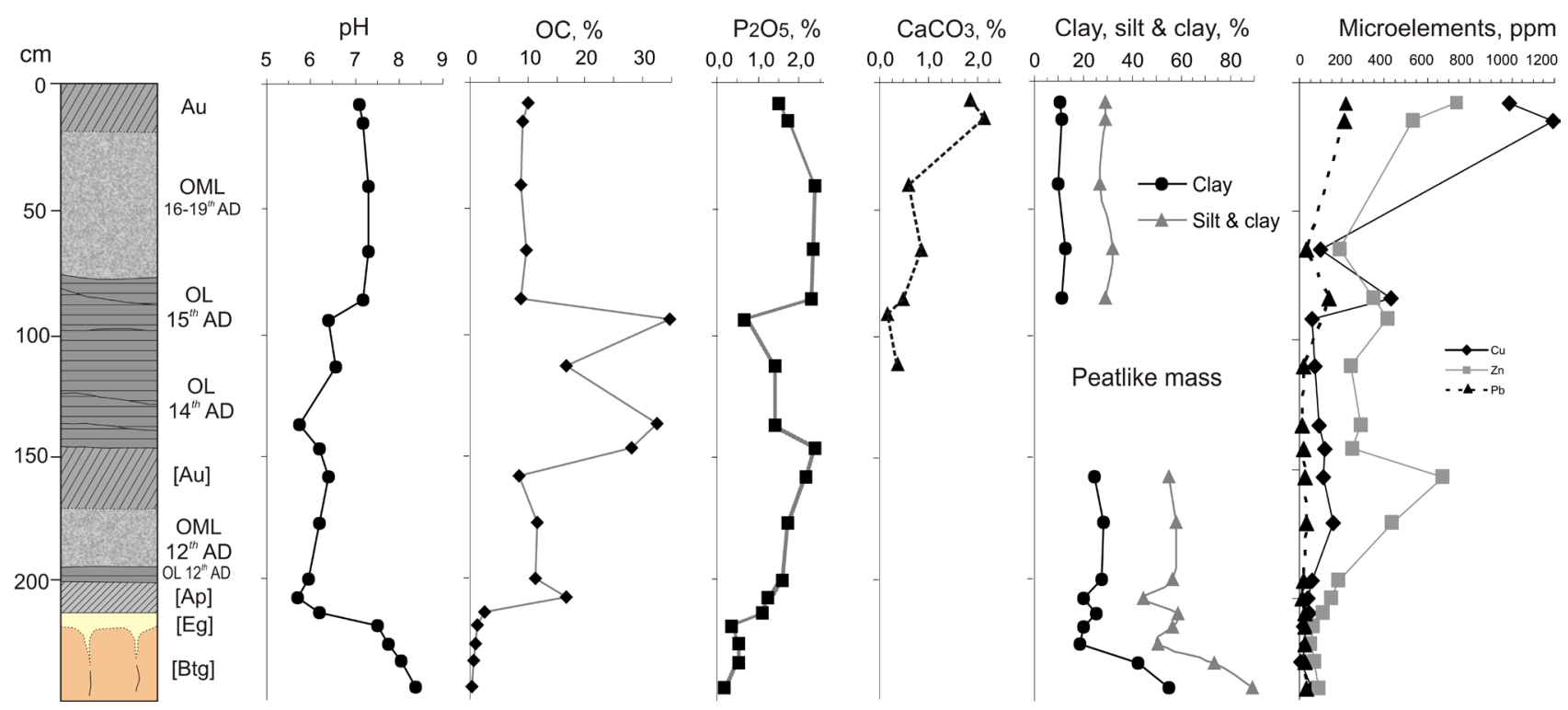

Figure 3. Velikii Novgorod, the Ilmensky excavation. OL is the urbo-organic layer, and OML is the urbo-organomineral layer. 

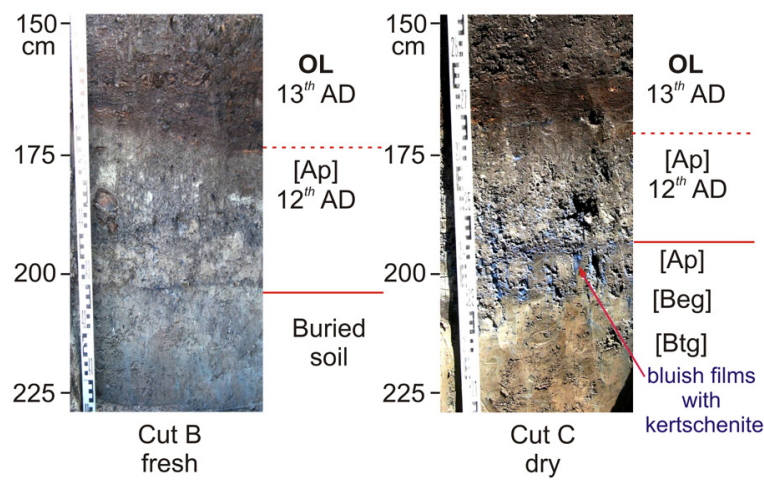

Figure 4. Velikii Novgorod, the Desytinny excavation. OL is the urboorganic layer; OML is urbo-organo-mineral layer.

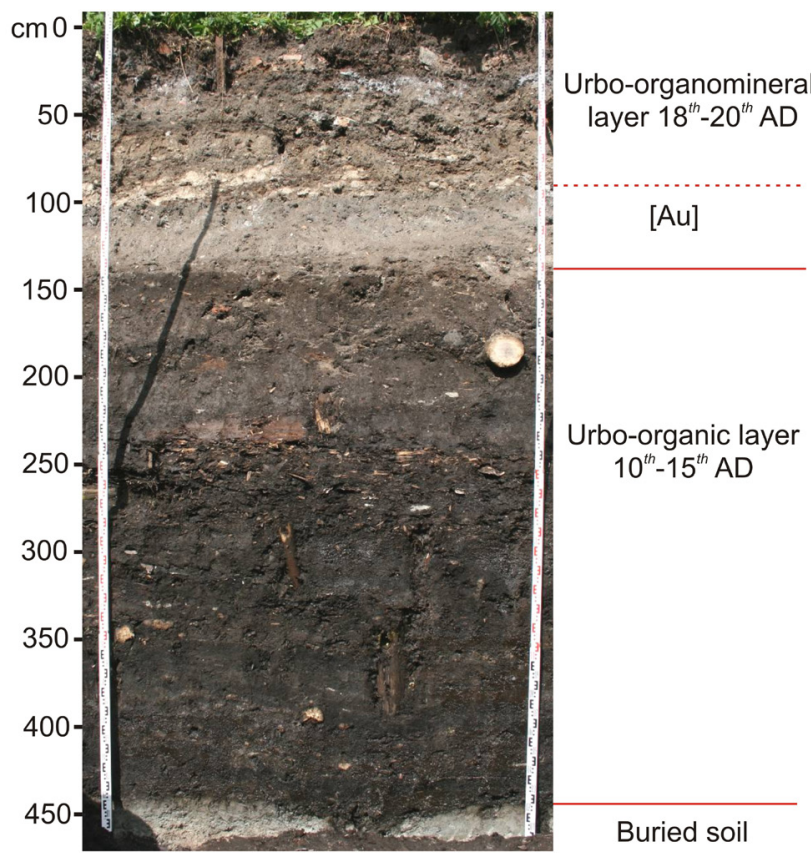

Figure 5. Velikii Novgorod, the Troitsky excavation.

accumulated during the $18^{\text {th }}-20^{\text {th }}$ centuries. It is much richer in the mineral mass, although the content of humified organic matter is also high. This layer is relatively dry. The wooden chips in it are strongly decomposed; inclusions of limestone, bricks, sand and clay interlayers, and lime are also present. The reaction is neutral to slightly alkaline $(\mathrm{pH}$ 7.5-8.0); the organic carbon content reaches 5-15\%. The phosphorus content is $1.5-3.5 \%$, and the content of $\mathrm{CaCO}_{3}$ is $1.5-8.0 \%$. In the layers enriched in ash, the content of calcium carbonates reaches $40 \%$.

We observed similar properties in the urbo-sediments with high organic matter content in other old urban centers of the forest zone - Rostov Velikii, Staraya Ladoga, and Staraya Russa (results not presented here).

Thus, the urbo-sediments of all the studied sites with high groundwater levels in ancient towns of the forest zone are characterized by the specific distribution of acid-base conditions with an alkaline reaction in the upper urbomineral layer, a slight acid reaction in the lower urbo-organic layer, and an alkaline reaction in the underlying buried natural soil. It is probable that the decrease in $\mathrm{pH}$ values within the organic layer is partially due to the production of acids during the decomposition of organic matter. Similar processes are reported in natural peatlands (Glagolev, 2008).

Urbo-sediments studied in Yaroslavl contain two layers: the lower organomineral layer $\left(12^{\text {th }}-17^{\text {th }}\right.$ centuries AD) and the upper urbo-mineral layer. Alkalization processes developed in the buried natural soil, and some acidification took place in the lower organomineral layer. In comparison with the lower organic layer in Novgorod, the organomineral layer in Yaroslavl is drier; it has a light loamy texture and a slightly acid or neutral reaction; the organic carbon content is approximately $10 \%$. The upper urbo-mineral layer is sandy loam, slightly alkaline ( $\mathrm{pH} 7.65)$, and depleted of organic carbon (3.5\%). Carbonates are present in the entire thickness of habitation deposits with a maximum of $8.4 \%$ in the upper mineral layer. The phosphorus content (about $1 \%$ ) is higher than that in the background soils, though it is not as high as in habitation deposits of Novgorod.

Urbo-sediments in the central part of Moscow are also separated into two layers: the lower urbo-organic layer and the upper urbo-mineral layer (Alexandrovskaya and Alexandrovskiy, 1997). Because of the rugged topography, the lower organic layers are only partly preserved in depressions or on broad leveled terraces (Figure 6).

In the site of Teplye Ryady (Kitai-gorod, Moscow), the urban sediments in two excavations reached a thickness of up to $5 \mathrm{~m}$. In excavation 1 , the lower organomineral layer (corresponding to the $13^{\text {th }}-17^{\text {th }}$ centuries) shows an increase in organic matter (up to $13.8 \%$ ). The reaction is slightly alkaline, and the content of carbonates in this layer is relatively low. The upper urbomineral layer (18th-20th centuries) is rich in debris such as bricks, lime, pottery, and bones. Its reaction is more alkaline $(\mathrm{pH} \mathrm{8.35),} \mathrm{and}$ the organic carbon content is relatively low $(4.2 \%)$. The calcium carbonate content reaches $10.9 \%$. The phosphorus content is higher (up to $1.2 \%$ ), although it is lower than that of the urbo-sediments of Velikii Novgorod. Excavation 2 is situated near excavation 1 , but the characteristics of urbo-sediments in it are different. The lower organic layer is strongly metamorphized, and its properties are closer to those of the mineral layers. Organic carbon varies from 0.5 to $7.5 \%$; the reaction is slightly acid or neutral ( $\mathrm{pH} 6.0-6.6)$, and the content of carbonates is low.

In general, the morphology and properties of urban sediments in the central part of Moscow and in Yaroslavl are similar. Well-developed organic layers, similar to those described in Novgorod, can be found in Moscow in large depressions in the relief and in buried river valleys and ravines. They are also present on flat interfluves, where they alternate with plots in which the organic layer is absent. At higher topographic positions in the upland areas, the thickness of the initial organic layer is reduced, transformed 


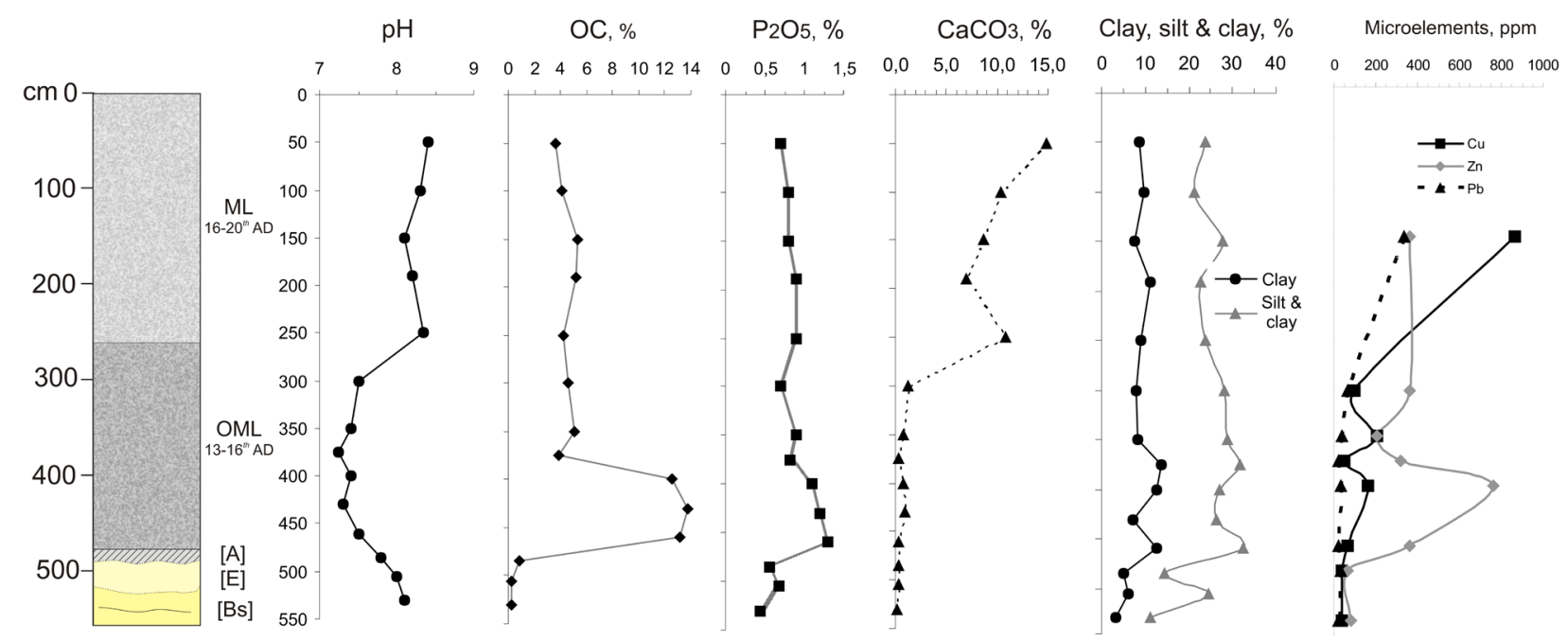

Figure 6. Properties of urbosediments in Moscow, the Teplye Ryady site, excavation 1. ML is the urbo-mineral layer, and OML is the urbo-organo-mineral layer.

into an organomineral or a humified mineral layer.

\subsection{Steppe zone}

Urbo-sediments in ancient towns in the southern sector of European Russia are formed under warmer drier climatatic conditions characteristic of steppe landscapes. Mainly mudbricks and stone were employed for town construction in antiquity and during the medieval epoch.

Urbo-sediments were studied in the central part of the ancient town of Phanagoria (the upper excavation, 2200 $\mathrm{m}^{2}$ ). The thickness of habitation deposits reaches $5.5 \mathrm{~m}$ and, according to the archaeological data, dates back to the $6^{\text {th }}$ century $\mathrm{BC}-9^{\text {th }}$ century $\mathrm{AD}$. Thus, the total period of anthropogenic sedimentation in this area was about 1500 years. Following abandonment, approximately 1100-1200 years ago, a Chernozem has been developing in the upper part of these deposits (Alexandrovskiy et al., 2010). A polygenetic loamy sandy soil is buried under the urban sediments. It has an upper light-humus A horizon underlain by a lamellar illuvial Bsm horizon and can be classified as a Lamellic Arenosol (Figure 7).

The thickness of urbo-sediments represents a layered light brown mass with laminae and lenses of light gray and dark gray material. In the lower part, the remains of mudbrick constructions are visible. There are also ash interlayers, ancient pottery, animal bones, and fragments of plaster.

Carbonates are present throughout, although their distribution in the profile is rather irregular. The organic carbon content is low (up to $1 \%$ ), with a slight increase in the mollic horizon $(2.27 \%)$ developed from the urban sediments. The phosphorus content is higher than in the background natural soils (up to $1.2 \%$ ) and comparable to that of the urban sediments of Moscow and Yaroslavl.
The formation of urban sediments in Hermonassa began in the $6^{\text {th }}$ century $\mathrm{BC}$; in contrast to Phanagoria, this ancient town has been functioning under different names (Tmutarakan, Matrega, Taman) since that time. The thickness of sediments accumulated over 2600 years reaches about $10 \mathrm{~m}$, including $5 \mathrm{~m}$ accumulated during the ancient epoch and $5 \mathrm{~m}$ accumulated in the medieval epoch (Alexandrovskiy et al., 2010). Underlying the urban sediments, the profile of a buried Chernozem developed from loess is found. A weakly developed Chernozem has formed from the uppermost part of these sediments (Figure 8).

Though the initial soils of Hermonassa and Phanagoria are different, the urban sediments of these towns have similar morphologies and properties. Moreover, the morphology and properties of medieval layers do not differ from those of the earlier layers. The organic carbon content in the urban sediments of Hermonassa is low (up to $1.2 \%$ ); the reaction is alkaline and strongly alkaline (pH 8.1-9.5); the content of carbonates reaches $5.7 \%$; the content of phosphorus reaches $1.2 \%$. The sediments have a loamy texture.

\section{Conclusions}

In the ancient cities of the forest and steppe zones of European Russia thick layers of urbo-sediments accumulated (average 3-5 m, in depressions up to 15-20 m) mostly derived from construction and household wastes. Surface pedogenesis and posterior diagenetic processes, at depth, considerably transformed the initial sediments. However pedegenetic features are rather poorly developed because duration of soil formation was strongly limited by the high velocity of deposition. 


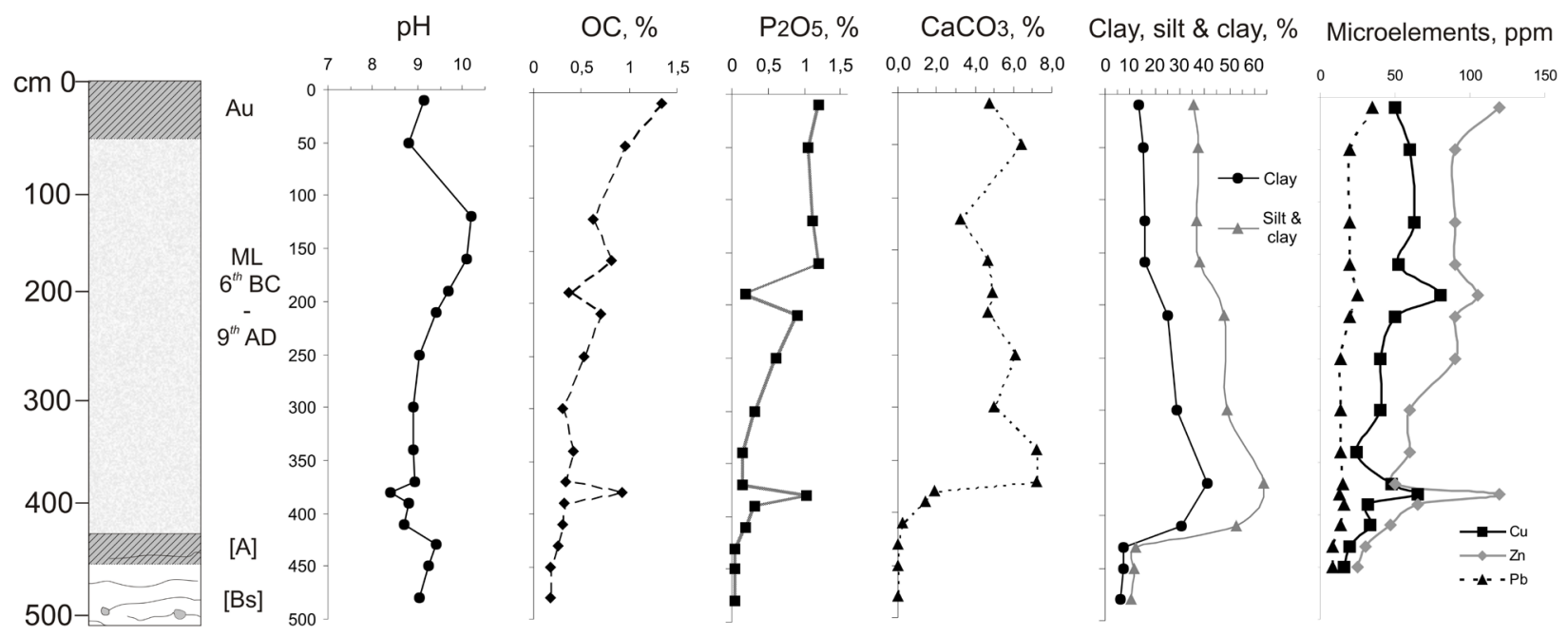

Figure 7. Properties of urbosediments in Phanagoria, the Upper Excavation. ML is the urbo-mineral layer.

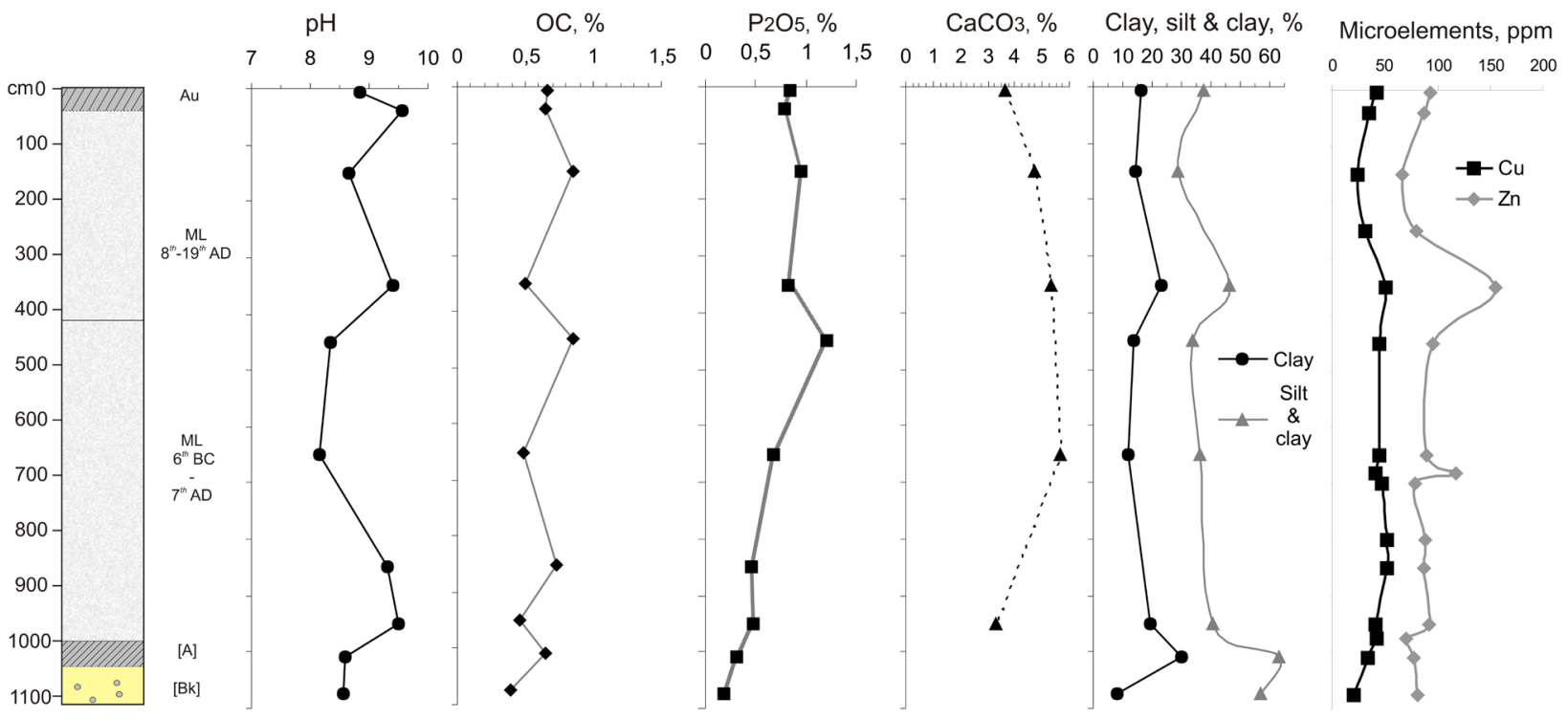

Fig. 8. The properties of urban sediments in Hermonassa. ML is the urbo-mineral layer.

A common feature of all urbo-sediments is their alkaline reaction which differs sharply from the natural soils which are often acid or neutral. With plant ash and lime used for the construction, carbonates are accumulated, which could be partly recrystallized to produce neoformed pedogenic calcite (mostly microcrystalline). Under the impact of carbonate leaching, the soils buried under the urban sediments are alkalized. The buried soil, the urban sediments, and the surface soil developing from them are formed under the impact of interrelated processes of pedogenesis and diagenesis and can be considered as a pedolithogenic system.

The properties of these urban soil-sedimentary bodies are quite stable and are usually not erased by natural pedogenesis in case the city was abandoned and natural or agroecosystems occupied its place. They are present as relict components - laminated urbo-sediments or as humusrich Anthrosols in the soil cover of the forest zone (Sedov et al., 1999).

The lower part of the urban sediments, accumulated in the forest zone under poor drainage, is wet and rich in organic matter and wooden chips. It is usually saturated with water. This organic layer contains up to $95 \%$ woody remains and peat-like mass. It is rich in phosphorus and may contain carbonates. However, as the organic matter decomposes, acidification takes place in this layer owing to the synthesis of organic acids. The migration of phosphoric compounds and the synthesis of vivianite-kerchenite also takes place in the lower part of urban sediments. Their upper part represents an organomineral layer of light loamy texture, 
rich in carbonates and phosphorus. Also in the forest zone, but under better drainage conditions, active mineralization of organic matter and partial humification take place. The thickness of the organic layer is reduced, and the main part of urban sediments is represented by the mineral layer.

Urban sediments accumulated in the steppe zone are quite different and represent a loess-like mineral material. The processes of the organic matter destruction and alkalization are clearly pronounced in these urban sediments. Contents of organic carbon, phosphorus and microelements $(\mathrm{Cu}, \mathrm{Zn})$ are much lower than in the organicrich layers of cities in the forest zone.

This contrasting difference among the properties of the humid forest and dry steppe regions allows us to conclude the existence of a "zonality" of urbo-sediments. This difference is partly related to the divergence of pedogenetic and diagenetic processes, directly controlled by the bioclimatic conditions. However, of equal importance is the compositional variation of the initial materials anthropogenic sediments: wood and organic plant materials are dominant in the forest regions; loam, clay and lime are more abundant in the steppe. Thus organic-rich urbo-sediments are dominant in the forest zone whereas such layers in the steppe area are dominated by mineral components. During the last 2-3 centuries the "zonal" differences of urbo-sediments diminished. The proportion of wood and plant materials decreased in the cities of forest zone and their upper part is mainly constituted by mineral components becoming more similar to urbo-sediments of the steppe.

\section{References}

Agarkova, M.G., Tselishcheva, L.K., Stroganova, M.N., 1991, Morphogenetic specificity of urban soils and their systematization: Pochvovedenie, 17, 11-16. (in Russian).

Aleksandrova, L.N. Naidenova, O.A., 1976, Laboratory Practice in Soil Science: Leningrad, Russia, Kolos, 294 p. (in Russian)

Aleksandrovskaya E.I., Aleksandrovskiy A.L., 1997, Accumulation of anthropogenic substances in the soils and cultural layer of Moscow, in the 12-19th centuries, in International conference Problems of Anthropogenic Soil Formation: Moscow, Russia, 4, 13-16.

Alexandrovskaya, E.I., Alexandrovskiy, A.L., 2000, History of the cultural layer in Moscow and accumulation of anthropogenic substances in it: Catena, 41, 249-259.

Alexandrovskaya, E.I., Alexandrovskiy, A.L., Gaidukov, P.G., Krenke, N.A., 2001, Woodland, Meadow, Field and Town Layout: Evidence from Analyses of the Earliest Cultural Deposits and Buried Soils in Novgorod; London, United Kingdom, The British Museum, Occasional Paper, 141, 15-21.
Alexandrovskiy, A.L., 2007, Pyrogenic origin of carbonates: Evidence from pedoarchaeological investigations: Eurasian Soil Science, 40, 471-477.

Alexandrovskiy, A. L., Alexandrovskaya, E. I., 2005, Soil Evolution and the Environment: Moscow, Russia, Nauka, 223 p. (in Russian)

Alexandrovskiy, A.L., Alexandrovskaya, E. I., 2009, The results of soil-geochemical studies of the excavation of Romanovs' yard, in Krenke N.A. (ed.), Archaeology of Romanovs' Yard: Prehistory and History of Moscow in the $12^{\text {th }}-19^{\text {th }}$ Centuries, Materials of Archaeological Studies, 12: Moscow, Russia, Inst. Archaeology, 176-195. (in Russian)

Alexandrovskiy A. L., Alexandrovskaya E. I., Dolgikh A. V., 2010, Evolution of soils and paleoenvironment of antique towns of south European Russia: Izvestia of the Russian Academy of Sciences, Series geographical, 5, 56-74. (in Russian)

Blume, H.P., 1989, Classification of soils in urban agglomerations: Catena, $16,269-275$.

Burghard, W., 1994, Soils in urban and industrial environment: Z. Pflanzenernährung und Bodenkunde 157, 205-214.

Dolgikh A.V., 2010, Formation pedolithosediments and the soilgeochemical environment of ancient cities European Russia: Institute of Geography RAS, Moscow, Russia, PhD dissertation, 175 p. (in Russian)

Dolgikh, A.V., Alexandrovskiy, A.L., 2010, Soils and cultural layer in Velikii Novgorod: Eurasian Soil Science, 43, 477-487.

Evdokimova A. K., 1986, Heavy metals in cultural layer of medieval Novgorod: Vestnik Moskovskogo Universiteta, Ser. 5: Geogr., 3, 86-91. (in Russian)

Glagolev M.V., 2008, Metanogenez of bogs (results and prospects of researches): Vestnik Tomskogo Universiteta, 4(78), 74-77. (in Russian)

Lehmann, A., Stahr, K., 2007, Nature and significance of anthropogenic urban soils: Journal of Soils and Sediments, 7, 247-260.

Norra, S., Stüben, D., 2003, Urban soils: Journal of Soils and Sediments, 3, 230-233.

Sedov, S.N., Zazovskaya, E.P., Bronnikova, M.A., Kazdim, A.A., Rosov, S. Yu., 1999, Late Holocene man-induced environmental change in central Russian plain: paleopedological evidences from earlymedieval archaeological site: Chinese Science Bulletin, 44, 159-165.

Stroganova, M.N., Agarkova, M.G., 1992, Urban soils: an experience in the study and systematization (by the example of southwestern Moscow): Pochvovedenie, 7, 16-24. (in Russian)

Stroganova, M.N., Myagkova, A.D., Prokof'ieva, T.V., Skvortsova, I.N., 1998, Soils of Moscow and Urban Environment. Moscow, Russia, PAIMS, 178 p. (in Russian).

Vorobyova, L.A., 1998, Chemical Analysis of Soils: Moscow, Russia, Moscow State University Press, 297 p.

Manuscript received: December 20, 2010

Corrected manuscript received: August 15, 2011

Manuscript accepted: February 15, 2012 